\title{
STRATEGIC PLANNING AND MANAGEMENT OF NATIONAL DEVELOPMENT PROCESSES IN LATVIA
}

\author{
Edvins Karnitis ${ }^{1}$, Maris Kucinskis ${ }^{2}$ \\ University of Latvia, \\ 19 Raina Blv, LV-1586 Riga, Latvia \\ E-mails: ${ }^{1}$ Edvins.Karnitis@sprk.gov.lv; ${ }^{2}$ Maris.Kucinskis@saeima.lv \\ Received 15 October 2007; accepted 18 November 2008
}

\begin{abstract}
Thanks to achieved productive collaboration of the highest level government institutions with the academic community experts, a national strategic planning system is shaping that is very significant for further development of Latvia. General principles of the system have been approved by the Law on Development Planning System. The conceptual document A Growth Model for Latvia: People First defines a knowledge-based human-centred development scenario. The National Development Plan has been approved as a mid-term programme for implementation of the Model. To monitor progress towards the goal an integrated quantified quality of life index was developed; the index includes priorities essential for Latvia's population and it is based on objective statistical data. Polycentric development and strong cooperation in the Baltic Sea Region are priorities among strategic tasks that have been outlined to realize the growth. But the current two-faced EU model cannot be evaluated as the most optimum and beneficial for development of Latvia as well as other EU Member States.
\end{abstract}

Keywords: national strategy, strategic planning, knowledge-based development, sustainable development, quality of life, Baltic Sea Region

\section{Introduction}

Disintegration of the socialist system in the early 1990 s was accompanied by the decline of economic and social indicators in all countries of Central and Eastern Europe. E.g., Latvia's GDP in 1995 was less than 40\% of the 1990 level. Stable and swift growth has begun since 1995, confident ascent of Latvia in the global rankings is very indicative (Fig. 1) (UNDP 2005).

Economic development issues of Baltic countries have been widely discussed recently (Ginevičius and

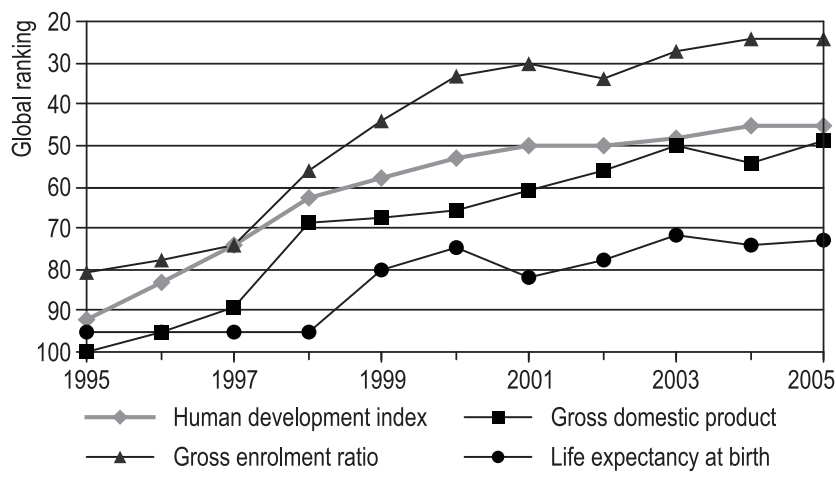

Fig. 1. Progress of Latvia in global ranking
Tvaronavičienė 2004; Tvaronavičienè and Grybaitė 2007; Tvaronavičius and Tvaronavičiene 2008; Tvaronavičienè et al. 2008; Tvaronavičienè and Tvaronavičius 2006). Slowdown of the progress clearly shows the urgent necessity of timely preventive activities to ensure further sustainable growth. But even the most decent measures and activities, which are not well-coordinated and are without common advancement, will not provide country for stable long-term growth and global competitiveness.

Therefore a strategic planning system is formed in Latvia, which is very much substantial for further development of the country, which accents the general growth trend and minimizes the major braking factors - uncertainties and risks that relate to coordination, continuity and sustainability of development processes.

\section{Unified national development planning system}

All higher state governance bodies have been involved in the planning system's forming; all of them have attracted experts (Fig. 2): 


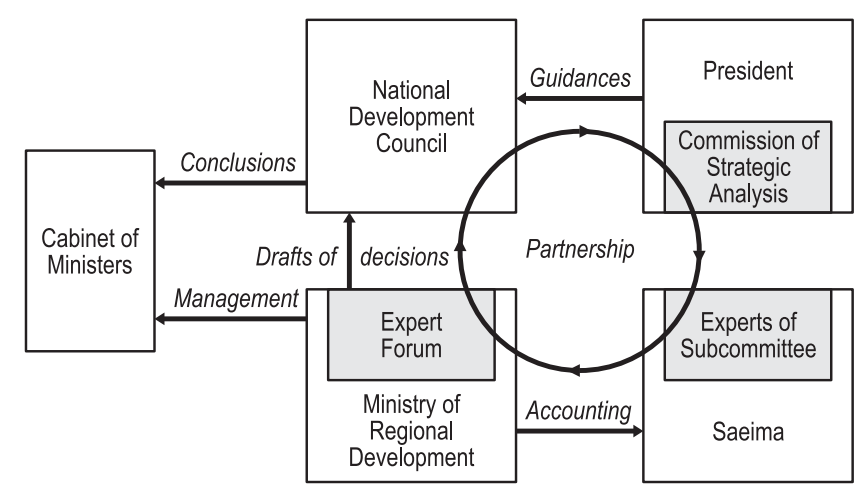

Fig. 2. Development planning system: partnership

- the President of Latvia; Commission of Strategic Analysis under the auspices of the President has been established to generate a long-term vision of Latvia's development through interdisciplinary and future-oriented studies in the context of international processes;

- the Saeima; according to its functions a special Subcommittee on Monitoring the Implementation of the National Development Plan was created and experts were involved in its activities; actually actions of the subcommittee are much more spacious, really it is an analogue of the Committee for the Future of the Parliament of Finland;

- the Cabinet of Ministers and the responsible Ministry of Regional Development and Local Government; an advisory expert forum has been created to assess efficiency of carried out activities as well to participate in dealing with national strategic problems.

To coordinate all activities for development planning, to supervise implementation of the programs, as well as to ensure concerted actions of governance institutions, regions, business, academic community and civil society there was established the National Development Council, which unites all driving forces under headship of the President of Ministers.

Exactly involvement of experts and their productive mutual collaboration is the real base of the successful work. Mainly representatives of the academic society are working as experts; academic society has overcome a syndrome, which was so popular in the nineties - to uninvolve in solving of strategic national-wide problems, because it is not presentable for a genuine scientist.

Principles for development of the country have been elaborated and corresponding Law on Development Planning System (will become valid on 1st January 2009) has been approved to promote development of the country and increase of the quality of human's life
(Law on Development ... 2008). The Law determines several substantial principles for successful development, including, but not only:

- sustainability, stability, continuity, balance;

- general inclusion and cooperation;

- resources forecast and estimation of financial possibilities;

- supervision and influence estimation.

The hierarchically structured system includes a number of closely interlinked and complemented development planning documents that have to be in accordance with the basic long-term conceptual document Growth model for Latvia (Fig. 3):

- Strategy for Sustainable Development is the unified long-term developmental document;

- a Growth Model and long-term strategy for sustainable development have to be approved by the Saeima;

- National Development Plan (NDP) is the basic midterm programmatic document; hierarchically it is subordinated to long-term strategy; the Plan has to be approved by the Cabinet of Ministers;

- all sectoral and regional mid-term documents are subordinated to the NDP;

- priorities and accents of the governmental activities should be directed to implementation of long-term strategy and NDP.

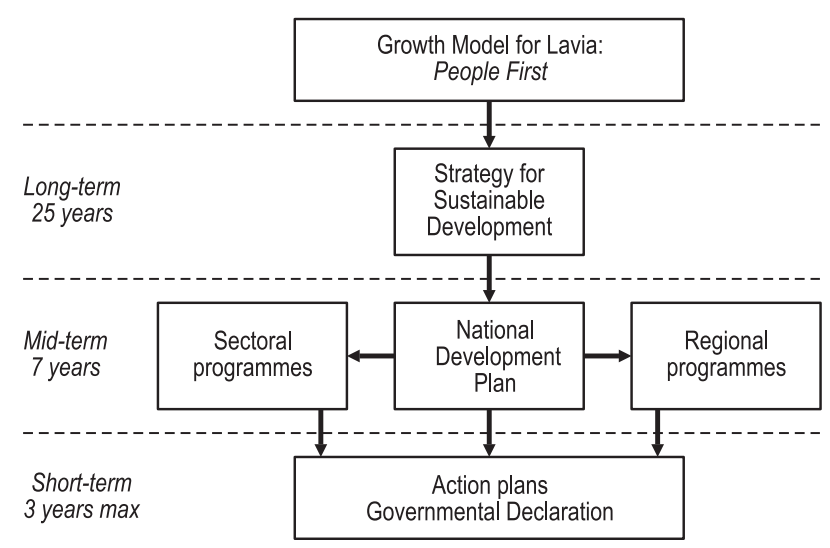

Fig. 3. Development planning system: hierarchy of components

Implementation of the planning system, its supervision and coordination is the task for Cabinet of Ministers and President of Ministers personally.

It should be stressed that such strategic planning does not mean a retreat from democracy and principles of the free market. Due to growing knowledge level of society, understanding deepens also about the free market; regulatory elements (patents, intellectual property, monopoly and competition regulation, etc.) have replaced the wild capitalism in the interests of the whole society. 


\section{A Growth Model for Latvia: People First}

The conceptual document $A$ Growth Model for Latvia: People First (approved by the Saeima in 2005) defines a knowledge-based human-centred development scenario in the context of global trends (Saeima of Republic of Latvia 2005). Its principal feature is fixing strong unity of the strategic trinity resources - goal - strategic activities on the national scale (Karnitis 2006).

The main resource for growth is the knowledge and wisdom of Latvia's inhabitants as well the ability of each individual to make use of this resource. Human beings as the creators, carriers and sole proprietors of knowledge are and will increasingly be the most important development factor. People become the focal point of our policy.

In order to make use of our development resource, all persons must be motivated to utilise their knowledge, to share their intellectual property with other people in order to achieve common benefits. Consequently development goals therefore need to be based on humancentred ambitions that correspond to the interests and priorities of most people. Human-centred goal - raising the quality of human life (QoL) in every aspect for each individual - is getting the highest strategic goal for the country's development.

Efficiency of usage of collective knowledge of all population becomes a determinant factor for development; bright example (Fig. 4) is a strong correlation between this and economy (The European Human ... 2006). Therefore general inclusion of all persons who live and work here becomes increasingly central for Latvia that has limited human resources; inclusion is not a catchword for us.

In achieving our goal we must make use of coordinated and balanced development of each aspect of life, taking into account networking and unity of activities and people. Expansion of these activities beyond

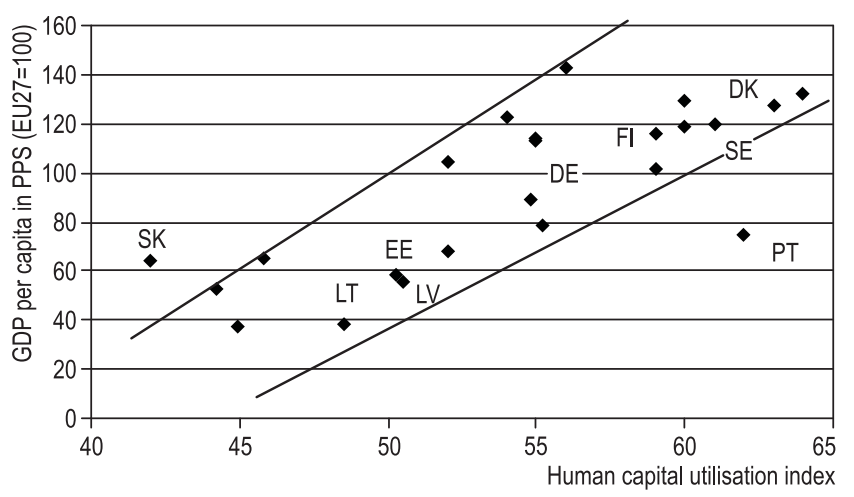

Fig. 4. Knowledge as a resource for growth (The European Human Capital Index 2006) frameworks of individual sectors, institutions, formal public structures and across borders (boundary spanning) is the necessary principle for implementation of the Model. Knowledge management, coordinated and targeted development, accumulation, sharing and utilisation of knowledge should become the cornerstone of economic and social development. It is the essence of the approved growth model for Latvia.

As a fundamental strategic document, the Model sets forth guidelines for drafting planning documents at all levels and sectors as well facilitates formation of a common understanding and involvement of the entire society.

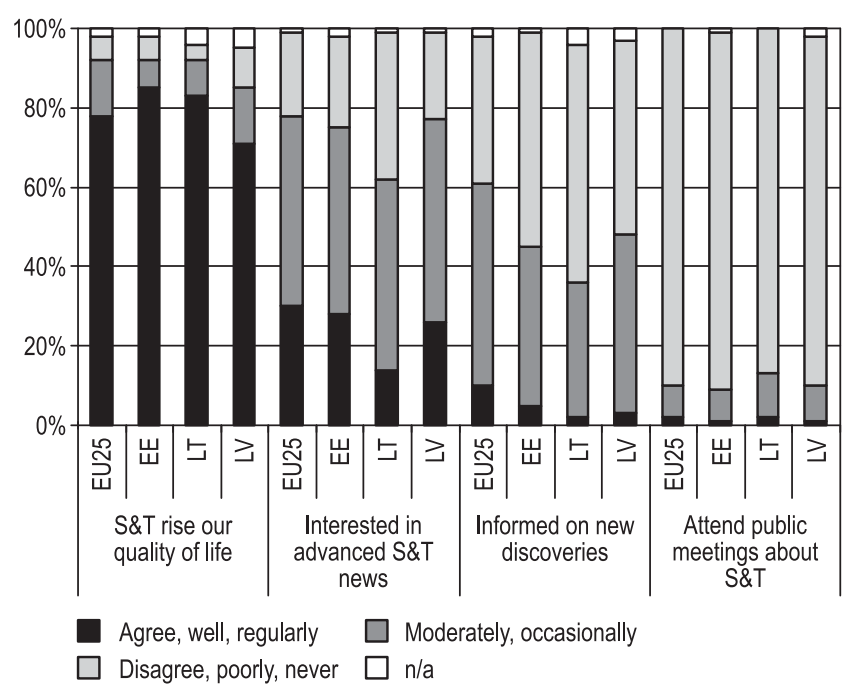

Fig. 5. Approach of the society to knowledge activities (Special Eurobarometer 2005); S\&T - science and technology

The problem today lurks in the people's minds. Public opinion poll (Fig. 5) shows that society strongly understands significance of knowledge, but people are only moderately interested; much more - in total, population is underinformed and inactive (Special Eurobarometer 2005). And a general approach is alike in other Baltic States and in the EU as a whole. Such situation has to be evaluated as very serious long-term risk factor for knowledge-based development.

\section{National Development Plan 2007-2013}

To outline a national development strategy, to start gradual transition to knowledge-based development model and thus to increase the QoL, the National Development Plan has been developed and approved by government as a mid-term programme for implementation of the Model in the period from 2007 until 2013 
(Cabinet of Ministers of Republic of Latvia 2006). The NDP includes a number of activities, they could be united in four closely interlinked action lines (Fig. 6):

- active mass-usage of the existent knowledge resource - innovation, increase of enterprises' innovative capacity, sharp growth of the efficiency of usage of existent resources (human resources, knowledge level, investments, etc.) to increase outputs (products, patents, licences, etc.), a selective governmental support to entrepreneurship (SME, export, etc.);

- enrichment and renewal of the knowledge resource, mass-production of new knowledge - fundamental science and applied research, commercialisation of their results;

- general acquisition of knowledge, increase of the human capital - education from kindergarten till lifelong learning, enrolment and quality of education, change of basic criterion from what we know to how we are able to apply knowledge;

- keeping knowledge holders, increase of the QoL of population - human-centred social model, attractive living space (health care, culture, security, environment, clean water, etc.), confidence about stability in future, cohesion of society (ethnic, regional, material and other aspects), the social participation and inclusion.

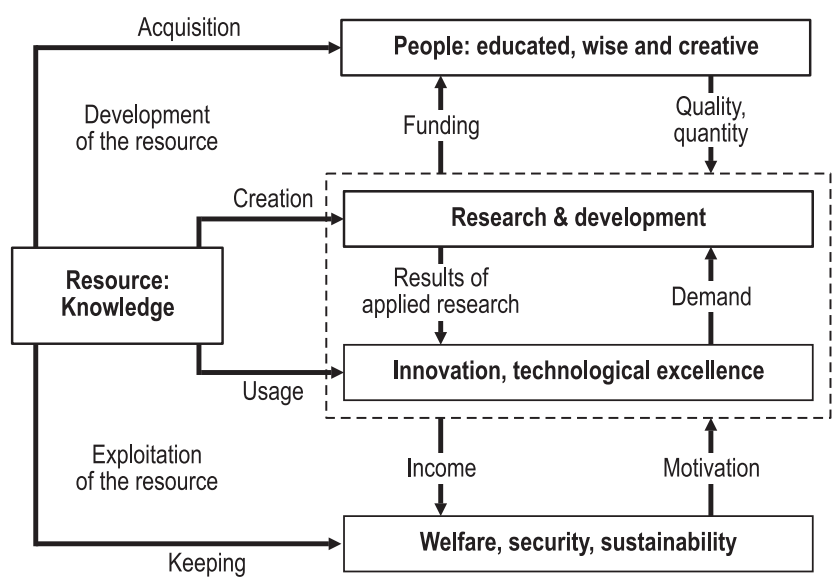

Fig. 6. National Development Plan: action lines

Any kind of innovation in any sphere is the basic principle. It should be stressed that all knowledge processes (including education, $R \& D$, etc.) in principle can be successful only as bottom-up processes, going out from a human as knowledge creator and holder, from an enterprise as a producer of products and their supplier to the market. Only motivated and seeing the personal purpose and benefit researcher, engineer, businessman can be successful; by pressure from above (top-down) innovative processes do not arise and do not work.
At the same time purposeful political and normative activities of the government considerably stimulate these processes.

Latvia is ranged as catching-up country (European Innovation ... 2007) thanks to high dynamism of the innovative development. Detailed investigation shows that innovation outputs (new products, patents, etc.) are inadequate to available resources (skilled human resources, expenditures, innovative enterprises, etc.). Problem of efficient usage of existing resources and capacity become even more topical than increase of resources (Fig. 7).

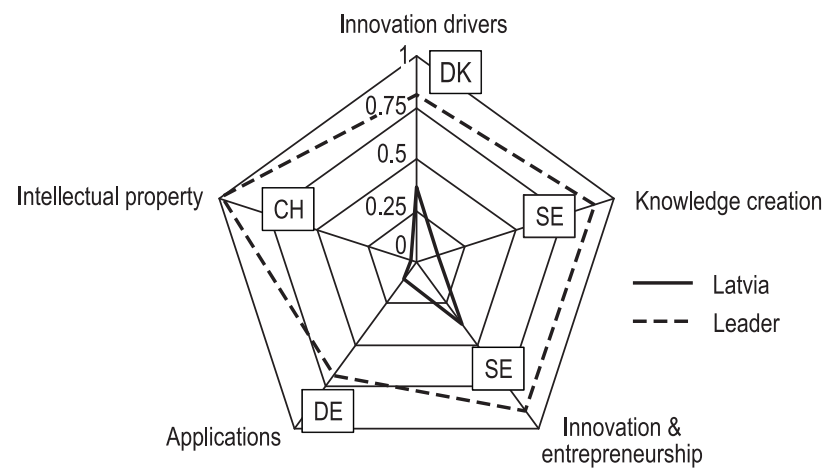

Fig. 7. Innovation performance: Latvia and the European leader (European Innovation ... 2007)

Innovative business has to become the most profitable type of entrepreneurship, private capital should be interested to invest in innovation, business people must have confidence in a good income. Therefore the Plan foresees to implement selective minimization of various barriers exactly for innovative business instead of the flat entrepreneurship support. This principle is developed by a number of concrete actions.

Taking into account an existing base and looking forward, support of specific type of innovation is included in the Plan - creative industries (audio, video, advertising, fashion, design, etc.). Experts are estimating this sector as a perspective one and with the high added value (1,8\% of Latvia's GDP in 2003).

There are particular problems for micro and small enterprises that are linked with their scale and capacity - large fixed payments and investments, insufficient supply of specialized e-business instruments, interfaces with large enterprises, etc. (Fig. 8). It is a typical situation in networked environment: there are objective difficulties for a small partner to utilize all benefits from networking; the real distance between him and the large partner is increasing that is one of the networking paradoxes. 


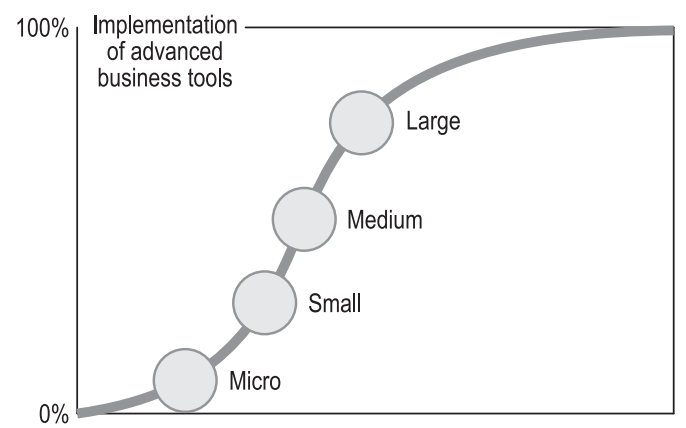

Fig. 8. Small networked partner needs particular support

It creates a real risk for small and micro business to be excluded from the network of partners/suppliers of the large enterprises. Therefore the support is especially accented for micro and small enterprises.

Capacity of research personnel of enterprises remains insufficient for development of new competitive products (share of R\&D personnel in business sector in 2006 was only $0,2 \%$ of total labour force, in comparison with $0,57 \%$ of EU27 average). Outsourcing of the $\mathrm{R} \& \mathrm{D}$, inclusion of academic community in commercialisation of results of the applied research remains the most problematic stage of innovative process. To increase motivation of researchers to engage in practical developments instead of theory, both financial factors (a year-on-year increase of government expenditures for R\&D on $0,15 \%$ of GDP) and moral factors (innovation will be equated to scientific achievements and patents - to scientific publications) are planned.

General acquisition of knowledge, capacity of the educational system plays the key role in knowledge-based development strategy. Aging human resources in science and technology create an additional problem for Latvia $(43,2 \%$ of researchers and engineers are $45+$ years, while only $38 \%$ in EU27 in 2006), but exactly thirty- and forty-years old people have demonstrated themselves as the most efficient innovators. Educational activities are strongly accented in the Plan.

Several even world standard gurus will not ensure development of the country; a strategic knowledge-based process is characterized by general participation, by mass-production and mass-usage of knowledge. That is why the Plan provides additional activities concerning all educational system - from preschool to the senior generation, concerning upgrading quality of education and increasing amount of persons, participating in different levels of formal or informal education.

And, certainly, various QoL aspects influence motivation to live and work exactly in Latvia (let us remember opened Europe!). For application of existing and creation of new knowledge, for an efficient economy on the whole territory of the country, public meaningfulness obtains life, health and capability of every individual. Therefore knowledge-based fundamentals will be strongly supported by issues that improve QoL for everybody (Fig. 9): healthcare and social system, employment, housing and environment, security, polycentric regional development, general participation and better governance.

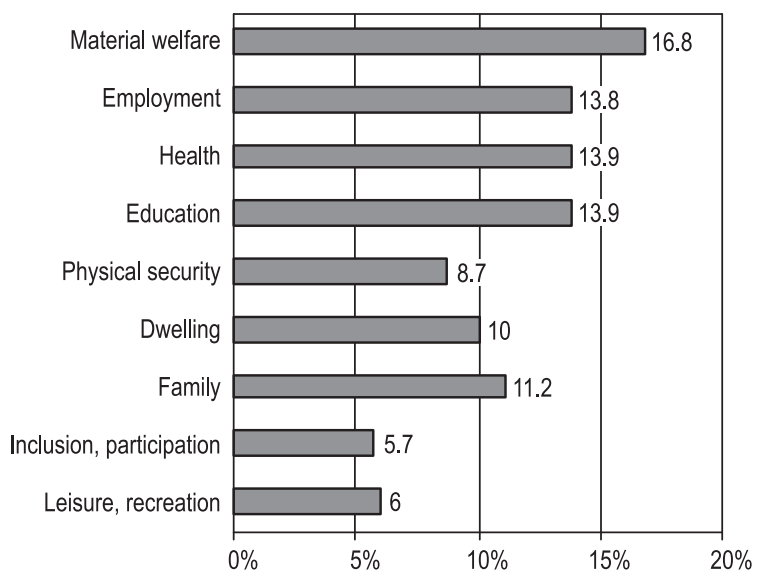

Fig. 9. QoL priorities for Latvians; destination. Public opinion surveys and expert estimation 2006

The Plan foresees to create such general environment, which stimulates parents to have children and facilitates them to combine the care of children with work and studies.

The purpose of another direction is an increase of physical and active lifetime. Activities are directed to raise comprehension of society on the health as a value, on the personal responsibility of every individual for saving the health. A number of activities foresee the further improvement of availability and quality of medical service, the social programs and issues of long-term stability of the pension system, minimization of different risk factors related to physical security of the people.

And, certainly, a snug living space. A varied supply of dwelling, high-quality environment, various and accessible cultural environment and services, wide possibilities of rest and recreation - these and other topics in the Plan are updated and specified.

Approved Growth Model and NDP have created a framework for development of a number of long-term activities: all knowledge-based processes (education, research, serious innovation) as well demographic, health care, inclusion activities. But there is critical necessity for wanting an interim planning document for long-term strategy (Fig. 3); current lack of this document should be evaluated as serious risk factor. 
Latvia was pressed to develop its NDP for the EU planning period of 2007-2013 and the right temporary decision was made: to work out real NDP that covers all sectors instead of a plan which includes only sectors that are under EU structural and regional funding.

To extend and implement long-term activities, to provide stability in growth, to give Latvia's population confidence in success (especially taking into account the fragmented political environment and, as a result, traditionally unstable short-term governments), a longterm strategy for sustainable development will be elaborated and approved in the nearest future.

\section{Quality of life index - a development indicator}

To monitor the implementation of the Plan, to evaluate progress in QoL regularly and objectively it was deemed necessary to propose quantitative criteria of the QoL, which would provide an objective assessment of the actual change of the QoL in Latvia. Therefore an integrated numerical quality of life index has been developed (Karnitis et al. 2007). The index includes priorities, which are essential for Latvia's population in the proportion relevant to our specific conditions, and which would allow maximum objectivity in identifying the annual comparative change of the QoL.

Public opinion surveys on the priority aspects of life quality and the activities for improving one's life are carried out regularly. They clearly point to similar priority aspects that are instrumental in increasing the quality of life of our population.

Indicators, which were selected for quantitative assessment of each aspect of life quality, are based on regular statistical information; the Central Statistical Bureau regularly provides their values. To measure most aspects, a single indicator is sufficient; however for comprehensive measurement of three aspects (material welfare, education and physical security) a combination of various indicators is used. Since the growth model is human-based, the indicators selected are related to the individual's perspective and interests, as opposed to the usual dominance of state interests in measuring development (e.g., an average monthly income and annual \% of inflation is used instead of habitual GDP per capita).

Obviously, interests and value priorities, ideas of a good and happy life differ from person to person, they are subjective and deeply personal, and, in addition, they change in course of a lifetime. Therefore to integrate the aspects and indicators, to determine their individual proportions in the summary assessment of life quality of Latvia's population, a wide range of experts was involved.

Material welfare continues to be the most essential aspect of life quality (Fig. 9); simultaneously the prevalence of the material aspects over employment, health and education is minimal - the time of the survival mode in the country is running out.

QoL index manifests a change in the quality of life in comparison with the previous year. Figures show a stable QoL increase every year (Fig. 10), but a contribution of individual aspects to the overall increase of life quality is quite different (the index of the reporting year shows the increase or decrease in comparison with the previous year).

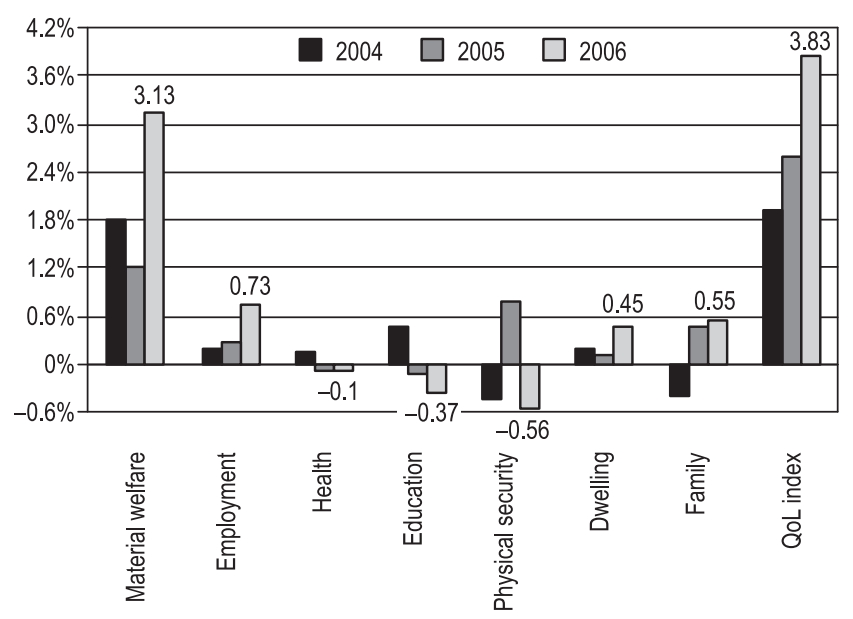

Fig. 10. QoL index and its aspects (2004-2006)

It is evident that even considering the non-dominant relative value of the material aspect and the comparatively pronounced increase of consumer prices, most of the QoL increase (up to 80\%) is attributable to the economic growth. A certain contribution is provided by increased employment, growing birth rate and construction of housing.

Simultaneously one can see insufficient transfer of economic successes to a social sphere; the weaknesses of Latvia's development are quite evident. Less than satisfactory is health protection and social programs. Sustained effort is necessary to increase the perceived value of education both among young people and adults (in its material and desirability aspects, prestige in the labour market, etc.); this failing, the adopted growth model for Latvia will not work. There is much room for improvement in the sphere of physical security.

Much balanced input is foreseen by the Plan in 20072013 with a 2,8\% average annual increase of the QoL (Fig. 11). Already today it is clear that implementa- 


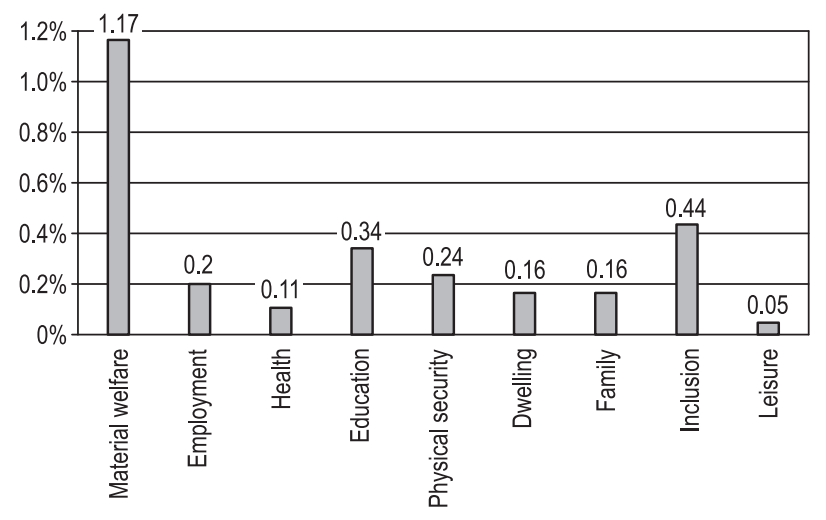

Fig. 11. QoL: planned average annual increase for 2007-2013

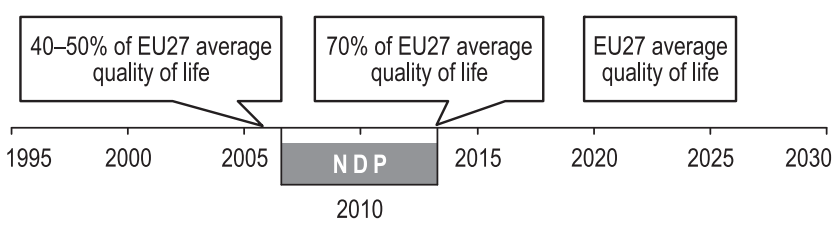

Fig. 12. Estimation of the QoL: Latvia and the EU

tion of this task will ask a large effort, corresponding financing and well-coordinated activities.

It is impossible to make a direct detailed comparison of QoL level in various countries and in EU as a whole, because of different mentalities and approach, different needs and core values of the inhabitants. There could be forecasted increase of QoL level in Latvia to $70-75 \%$ of EU27 average level in 2013 (Fig. 12) and achievement of EU27 level in 2020-2025.

\section{Polycentric development}

Among strategic tasks that have been outlined to realize the growth, inland and foreign partnership in the broad sense is mentioned as the priority.

To ensure development and exploitation of the knowledge resource in full and to increase QoL for everybody, progress has to be achieved on the whole territory of the country. Polycentric development becomes a principal trend.

An unbalanced development, economic and social disparities between regions characterize current monocentric situation in Latvia (Fig. 13). Riga's GDP per capita more than 4 times exceeds an indicator of the weakest Latvia's region Latgale; almost as large there are differences in non-financial investments. At the same time salary level in the country is incomprehensibly more equal: in Riga it is only 1,5 times higher than in Latgale. And population assess their quality of life quite identically.

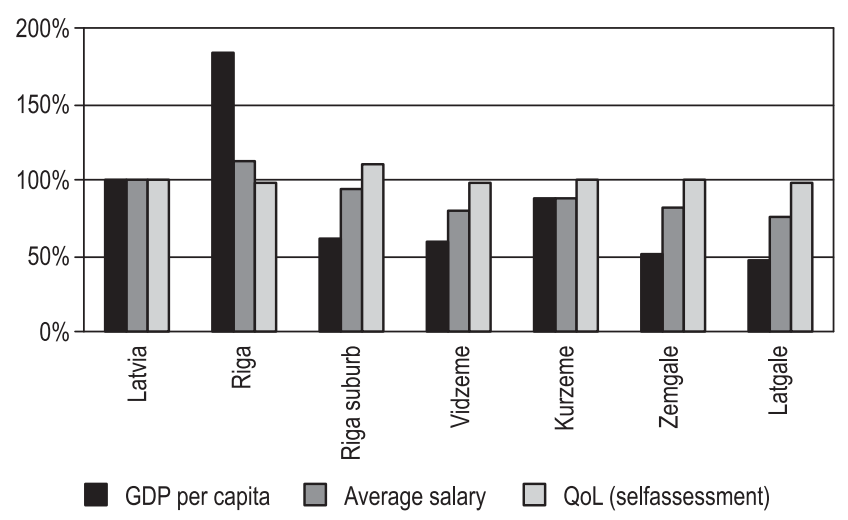

Fig. 13. Regional disparities in Latvia

The common saying is - Riga is a knowledge, business, research, cultural metropolis. Riga's economy (57,3\% of Latvia's GDP in 2006) today can be characterized as an economic system of the metropolis, which exceeds city borders far. Also, the Latvia's knowledge potential is concentrated in Riga to a great extent. Riga's knowledge capacity characterizes $62 \%$ of Latvia's public and private scientific institutions, $70 \%$ of public and all private higher educational institutions with $80 \%$ of students, both major technological centres (Latvian Technological Centre and Latvia Technology Park).

The Plan proposes algorithm for successful usage of Riga's excellence, potential and resources for development of other regions.

In the first stage Riga has to radiate knowledge to other territory of the country, thus increasing faith and persuasion of the potential innovators in their performance; wherewith deeper specialisation and labour/competence sharing will appear. Such radiation of knowledge, excellence, innovation has to be purposefully directed to the regional development centres, in which the development and innovation potential concentrates, that can usefully absorb the Riga's radiation.

When competence level of the regional centres increases, feedback appears in the second stage, in which regional partners contribute to Riga as well.

To implement aforementioned scenario a regional development centre has to be a real knowledge hub, containing higher educational institution with research institutes, technological/business centre/park, technology transfer centre and library/information centre.

Actually only four development regions (Kurzeme, Latgale, Vidzeme, Zemgale) can appear in addition to Riga. It should be mentioned that development regions and administrative regions are not synonyms. Their functions are too different. 
Today only Jelgava really possess the critical mass of knowledge. A positive development shows Ventspils in cooperation with Riga Technical University and Daugavpils in cooperation with private Transport and Telecommunications Institute. There are possibilities to involve Liepaja, Rezekne and Valmiera in the process.

\section{Latvia in the Baltic Sea Region: necessity for single knowledge space}

The highest value added will be produced if we could implement complete creative process starting with $\mathrm{R} \& \mathrm{D}$ (even education) up to the final production and sale of the knowledge-capacious products.

But limited human resources and a small economy are objective restrictive factors for Latvia and its companies (we are only $0,034 \%$ of humanity and our demographic prognosis does not show increasing population in the nearest future; our GDP in PPS is around 0,055\% of the world GDP). For this reason, transnational partnership becomes a substantial issue for us; country needs to participate in the innovation process as a fullyfledged partner. Participation in partnership networks and the division of labour is a necessity for us.

All neighbouring Baltic Sea Region (BSR) countries during centuries have been united through their location in the region of pronounced geopolitical interest, common history, multicultural society and also a similar vision of the future (Karnitis 2004). Today BSR is an excellent association of strong and dynamic countries, their GDP proportionally considerably exceeds amount of population (Fig. 14), they are taking internationally acknowledged positions in various global rankings. Nevertheless, alike Latvia, human resources of other BSR countries are also too limited to have long-term strength to compete with global leaders. But the collective capacity of the Baltic and Nordic countries both in the EU and on a global scale should be taken into account $(0,48 \%$ of world population and even $1,53 \%$ of world GDP).

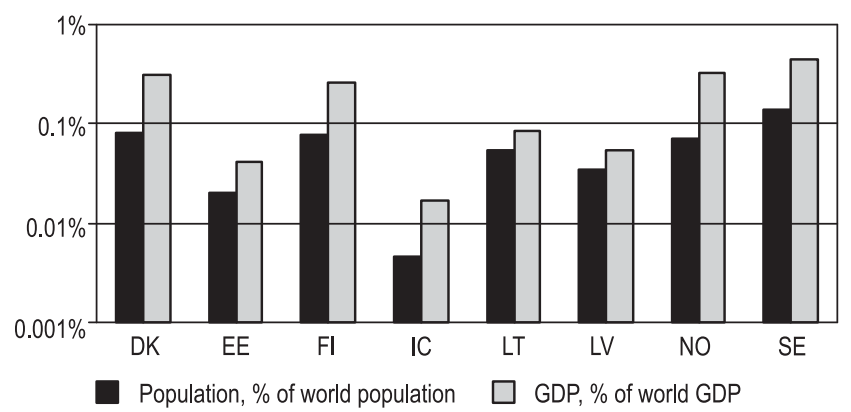

Fig. 14. Baltic Sea Region countries: human resources and GDP
The BSR context becomes extremely important for Latvia's and our neighbours' sustainable development; close cooperation within the BSR is the chance and challenge for these countries. Therefore the NDP accents a necessity to promote a closer integration of the BSR to catalyse growth by joint utilization of resources and possibilities of the region.

The Hanseatic League, the economic and political formation that in the 14th-15th century united the cities of the Baltic and North Sea region had shown tendency of the region to mutual cooperation. It becomes once more very significant in the 21 st century, it will help all region countries to achieve the effect of synergy.

The region is a very smart area; it has always respected knowledge and, at present, it has accumulated enough wisdom and human resources to develop a knowledge economy. Knowledge-capacious products and services comprise a significant part of the national economies already today.

All Nordic countries are ranked as innovation-driven economies, Latvia, Lithuania and Poland - as efficiency-driven economies and Estonia - as being in transition to innovation - driven-economy (World Economic Forum 2007). Factor-driven model, which is based on low value added products and processes, is not actual in BSR countries.

Also, development goals are similar for all region states. Understanding of the substantial role of scholars in the 21 st century, which is a logical continuation of the centuries' long intellectual traditions, an increase of the QoL logically is on the top of the priorities for all countries. During Baltic Sea Region Summit In Riga (June 2008) leaders of BSR countries confirmed the fundamental principle that had been put in the basis of Baltic Sea Region Council: “...the essential objective of Baltic Sea Region co-operation is the constant improvement of the living and working conditions of their peoples" (Presidency Declaration 1996).

The economic and social policy of the countries is much more humane by comparison with other states, much more inclined to the social solidarity, more secure for society and individual. All BSR countries (similarly all other EU Member States) are classified as high human development countries (Fig. 15).

Unity of resources and goals is a stable foundation for closer integration. All BSR states are interested in closer partnership and unity; it is a precondition for increasing competitiveness of all countries of the region. Countries of the region are aware of the need to function jointly; it is the right time to raise cooperation of countries to a higher level. 


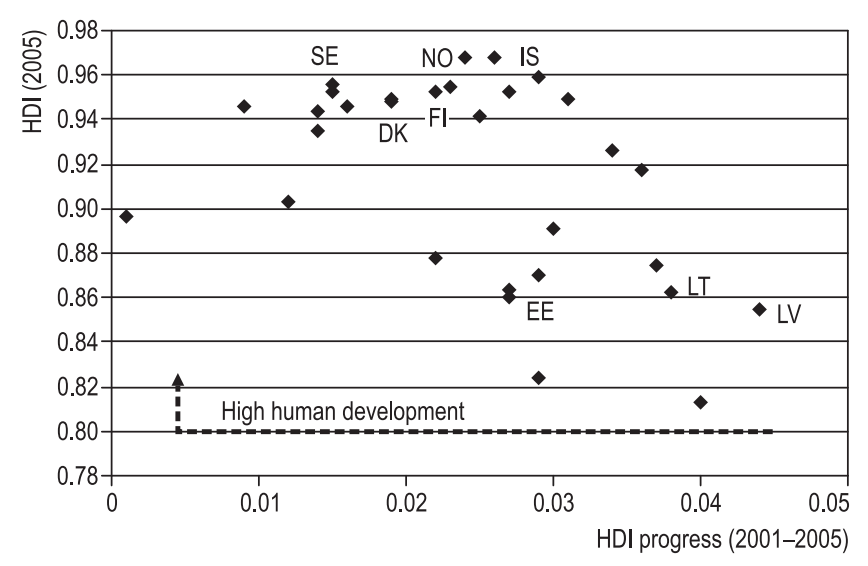

Fig. 15. Human Development Index; ranking positions of the EU countries

Creation of single knowledge space in whole BSR that includes the whole process education - research - innovation - development of products - production market, that consolidates the knowledge potential of all BSR countries, that is focused on forming international clusters should form the environment for collaboration model. Each state applies its knowledge potential, achieving the necessary synergy; close integration will become beneficial for all partners.

Practical realization of the knowledge space could be based on a network of metropolises of the BSR (Hanseatic League of the 21st century!). In the comparatively small BSR countries metropolises are the most real knowledge centres. Because of tendency to concentrate knowledge, creation of the network of metropolises will strengthen their mutual cooperation abilities; it will be an effective instrument to achieve the needed synergy.

On the other hand, metropolises as knowledge hubs of national significance are an important developmental driving force for the neighbouring regions, transforming its booties and promoting development of the region and whole country. It will provide the necessary preconditions for the development of well-balanced Baltic Sea Region.

Experts of the BSR states have gone into a detailed discussing for such development scenario in many conferences and meetings. There is a unified approach - it is optimum for all region countries. No country and no individual can exist in isolation. Only common policy and cooperation among all partners will give all BSR countries opportunities to find the best ways how to use their advantages and potentials, to minimise the influence of week points.

Diplomats and governments have to act now, forming the necessary political and normative base for the sin- gle knowledge space and collaboration of incorporated countries. A transnational political agreement of BSR countries (e.g., in the framework of Baltic Sea Region Council) is necessary to strengthen innovators' confidence in long-term stability of the policy. The following legal documents mean introduction of harmonized normative environment in the BSR, and, thus, promoting and accelerating innovation processes.

\section{Latvia in the EU: on a way to optimum EU model}

Knowledge-based development model, of course, is not a priority for Latvia only. The decision adopted at the Lisbon Summit Meeting in 2000 precisely defines this way as a strategic goal in the development of all Member States (MS) and the Community in total (European Parliament 2000). How successful is the EU (and Member States too) in carrying out the Lisbon strategy?

The generality of EU citizens are sure that in the EU as a whole things are going on more rightly than in their own countries (European Commission 2006); difference is 20 percent points that is a much higher figure than statistical dispersion.

At the same time similar innovation inputs (human and financial resources) in EU27 provide much less outputs - productivity, material and intellectual products than in the USA (Table, 2006 or last available year).

There is no reason to think, that European's intellect is less capable. Obviously, fractioning of resources and the weak collaboration of the MS remains a basic weakness. A question appears naturally - is all done to implement knowledge-based scenario, int. al., is the current EU organizational model the most optimum for Latvia, for any Member State and whole EU to achieve the set goals?

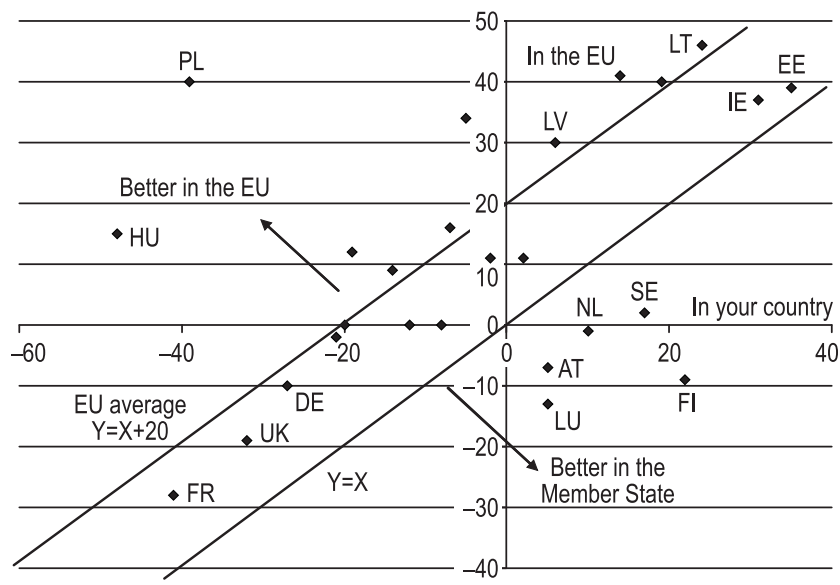

Fig. 16. Are things going in the right direction? (European Commission 2006) 
Acceptance of the strategic decisions, which are necessary to work towards the set out common objectives, for community of 27 independent countries is heavy, long-drawn and far not always successful. The next step is accent on mandatory for all MS (resp., far not always optimum for any country) tactical instruments and regulations, which is the typical principle for a federal state, but too hyperbolic approach for network of countries. Really, today the current governance model (decision-making and action) is time-consuming and not optimum.

Knowledge-based development indicators

\begin{tabular}{lcc}
\hline & EU27 & USA \\
\hline $\begin{array}{l}\text { Spending on human resources } \\
\text { (\% of GDP) }\end{array}$ & 5.09 & 5.12 \\
\hline $\begin{array}{l}\text { S\&T graduates (\% of population aged } \\
\text { 20-29 years) }\end{array}$ & 1.29 & 1.06 \\
\hline ICT expenditure (\% of GDP) & 5.7 & 5.4 \\
\hline $\begin{array}{l}\text { Labour productivity per person } \\
\text { employed, \% }\end{array}$ & 100 & 140 \\
\hline \begin{tabular}{l} 
GDP per capita, \% \\
\hline Annual GDP growth rate (2000-2006), \%
\end{tabular} & 2.2 & 2.6 \\
\hline $\begin{array}{l}\text { High-tech exports (\% of total exports) } \\
16.7\end{array}$ & 26 \\
\hline $\begin{array}{l}\text { Patent applications to the EPO } \\
\text { (number per million inhabitants) }\end{array}$ & 112 & 117 \\
\hline $\begin{array}{l}\text { Patents granted by the USPTO } \\
\text { (number per million inhabitants) }\end{array}$ & 58 & 352 \\
\hline
\end{tabular}

Economies of the MS remain separate ones, but vitally important sectors (energetics, telecommunications, agriculture) are centrally overregulated. Free movement of people in the EU results in free flow of knowledge; educational and research potential of some MS is working for another economy. But these economies are acting more frequently as competitors than in perfect unison.

The EU potential is not utilized and global competitiveness remains low. It became necessary to reduce substantially goals of the Lisbon strategy in a mid-term (The Lisbon strategy ... 2004), because of poor coordination, irreconciled priorities and lack of political resolve; ambitions to become the most dynamic and competitive economy in the world were cancelled. But we continue lagging behind the USA; China and India come up closer by leaps and bounds.

And also the renewed Lisbon strategy will not be successful at the current EU model. It does not provide neither necessary unity of the resources and goals, nor an observance of the basic strategic principles; first thing it belongs to general inclusion and boundary spanning principles (current action style of the European Commission is the brightest example).

Of course, the current situation is not the most beneficial one for all EU MS. It seems that a model of a strong federal state would be more profitable to all Member States. When integration of states is closer, actions will become more efficient. This issue is of particular importance.

$\mathrm{EU}$ is on this way. The current development of the EU in its essence means political and economic innovation. The EU is gradually acquiring major indicators of state integrity: a border, currency, foreign policy, normative environment and European patents.

The current contradictionary half-way situation is the most dangerous; it has to be overcome as soon as possible. Creation of the single knowledge space in the BSR would become a serious pilot project on this way. Federalisation of EU is advantageous for all Member States; this is a substantial guarantee for our competitiveness and sustainability. But the global processes do not give us a long time to prepare. It can be estimated that in the next 5-7 years positions have to become clear and strategic decisions should be approved. And therefore purposeful and prompt creation of the single knowledge space in the BSR is in the interests of the whole EU.

\section{Conclusions}

Latvia has overcome the frame of mind in the first independence years - nothing will be planned in future, a market will solve all problems. An achieved productive collaboration of the highest level governance of the country (decisions' making and execution institutions) with the academic community (experts) is very substantial for development of the planning system.

Elaborated principles and approved documents form the kernel of the system. At the same time it should be underlined that process has been started only. A strategy for long-term sustainable development and a number of sectoral and regional strategic documents have to be worked out. Monitoring and management of the development process have to be implemented. Therefore it is very important to recognize and minimize existing major risk factors or their influence on our growth:

- moderate motivation and interest as well inactivity of population in knowledge-related activities; 
- potential lack of continuity, sustainability and stability of the development strategy due to frequently changing governments;

- limited human resources and a small economy, slow or unsuccessful integration of Baltic Sea Region countries;

- weaknesses of current EU model, uncerntainties and time-lag related to EU further development way.

Current slowdown and global problems related to energy and food sectors create additional difficulties.

\section{References}

Cabinet of Ministers of Republic of Latvia. 2006. Latvian National Development Plan 2007-2013. Available from Internet: $<$ http://www.nap.lv/eng $>$.

European Commission. 2006. Standard Eurobarometer 66. Available from Internet: <http://ec.europa.eu/public_opinion/standard_en.htm>.

European Innovation Scoreboard 2007. Available from Internet: $<$ http://www.statistik.at/web_de/static/subdokumente/b_ cis_eis_2007.pdf>.

European Parliament. 2000. Presidency Conclusions. Lisbon European Council 23-24 March, Lisbon. Available from Internet: <http://www.europarl.eu.int/summits/lis1_en.htm>.

Ginevičius, R.; Tvaronavičienè, M. 2004. Risk of Globalization: Case Study of Lithuanian Economy, Ekonomický Časopis [Journal of economics] 2: 212-231.

Karnitis, E. 2004. Baltic Sea Region - a Leader in the Development of Information Society, in Latvia in Europe: Visions of the Future. Riga, 148-168.

Karnitis, E. 2006. A knowledge-based human-centred growth model for Latvia, Journal of Business Economics and Management 7(1): 95-101.

Karnitis, E., et al. 2007. Quality of life index for Latvia, in Yearbook of politics: Latvia 2006. Riga: Zinâtne, 131-149.

Law on Development Planning System. 2008. Available from Internet: <http://www.likumi.lv/doc.php?id=175748> (in Latvian).
Presidency Declaration. 1996. 1st Baltic Sea States Summit. Visby, Sweden 3-4 May. Available from Internet: $<$ http:// www.cbss.st/summits>.

Saeima of Republic of Latvia. A growth model for Latvia: People First. 2005. Available from Internet: <http://www. saeima.lv/bi8/lasa?dd=LM0815_0\#b > (in Latvian).

Special Eurobarometer. 2005. Europeans, Science and Technology. Available from Internet: $<$ http://ec.europa.eu/public_opinion/archives/ebs/ebs_224_report_en.pdf $>$.

The European Human Capital Index. 2006. Available from Internet: $<$ http://www.lisboncouncil.net/index. php?option $=$ com_publications \& task $=$ view $\& i d=8 \&$ Item id $=35>$.

The Lisbon strategy for growth and employment 2004. Facing the Challenge. Available from Internet: $<$ http://europa. eu.int/growthandjobs/pdf/kok_report_en.pdf $>$.

Tvaronavičienè, M.; Grybaite, V. 2007. Impact of FDI on Lithuanian economy: insight into development of main economic activities, Journal of Business Economics and Management 8(4): 285-290.

Tvaronavičienė, M.; Grybaite, V.; Tvaronavičius, V. 2008. Economic and other development aspects of Baltic countries: estimation issues, in The $5^{\text {th }}$ International Scientific Conference: Business and Management 2008. Vilnius, Lithuania May 16-17. Selected papers. Vilnius: Technika, 2008, 107-115. ISBN 978-9955-311-9.

Tvaronavičienè, M.; Tvaronavičius, V. 2006. Kai kurie Lietuvos ekonominio augimo aspektai [Some Aspects of Lithuanian Economic Growth], Verslas: teorija ir praktika [Business: Theory and Practice] 7(4): 232-236.

Tvaronavičius, V.; Tvaronavičienè, M. 2008. Role of fixed investments in economic growth of country: Lithuania in European context, Journal of Business Economics and Management 9(1): 57-65.

UNDP (United Nations Development Programme). 2005. Human Development Report 2005. Available from Internet: $<$ http://hdr.undp.org/en/reports/global/hdr2005>.

World Economic Forum. 2007. Global Competitiveness Index 2007-2008. Available from Internet: $<$ http://www.weforum.org/en/index.htm>. 